\title{
Emotional Intelligence in the Concept of Western Psychology and Islamic Psychology
}

\author{
Linda Yarni ${ }^{1}$, Afrinaldi ${ }^{2}$, Muhammad Arif ${ }^{3}$ \\ $\left\{\right.$ linda_psi78@yahoo.co.id ${ }^{1}$, afrinaldi_04yahoo.co.id ${ }^{2}$, m_arif1205@yahoo.co.id $\left.{ }^{3}\right\}$ \\ Institut Agama Islam Negeri (IAIN) Bukittinggi, Indonesia ${ }^{1,2,3}$
}

\begin{abstract}
Every human is intelligent and the intelligence has so broad meaning that it is needed in life. One's success will be determined by the intelligence,the success in everyday life, in the learning process, or in working. Emotional intelligence will be able to help a person know himself, manage the emotions, self motivate, than when he faces problems he will not harm himself and others. Inwestern psychology, emotional intelligence is introduced by Daniel Goleman while in Islamic psychology, it is derived from the Qur'an and Hadith. Inwestern psychology, the emotional intelligence aspect includes five aspects, namely self-awareness, managing emotions, self-motivation, recognizing the emotions of others and being able to socialize with others. While in Islamic psychology, emotional intelligence includes the following aspects of sowing affection on earth, understanding the feelings and circumstances of others, respecting and appreciating oneself and others, muraqabah (alert and introspective), friendly to the environment
\end{abstract}

Keywords. Emotional Intelligence, Psychology, Islamic Psychology

\section{Introduction}

Every human is intelligent and intelligence is so broad meaning that it is needed in life. One's success will be determined by the intelligence it has both success in living everyday life or in work. Intelligence is not only intellectual, but multiple intelligence, emotional, spiritual and others.

Intellectual intelligence (IQ) is closely related to problem solving, decision making and adjustment. Emotional Intelligence (EQ) deals with the ability to overcome problems without despair, get along well with self-understanding and others. Spiritual intelligence (SQ) is said by Emmons (cited by Yosi Amram, 2016) involves a set of abilities that utilize spiritual resources, referring to individual pursuits, and elements of experience from, sacred, meaning, heightened awareness, and transcendence which puts greater emphasis on utilizing such spiritual themes to predict function and adaptation and also produce valuable products or results (Emmons in Yosi Amram, 2016).

High intellectual intelligence (IQ) does not guarantee prosperity, prestige, or happiness in life. In recent years, psychologists such as Gardner, Salovy and Stenrberg have agreed that the old concept of intellectual intelligence (IQ) is very narrow in interpreting intelligence (only about mathematical and linguistic ketermapilan) and only good in predicting success in the class as well as to become professors and less important in non academic life. Therefore, emotional intelligence (as well as intellectual) is also very important to be possessed by an individual. Emotional intelligence is a meta of ability that determines how well a person uses 
his / her own skills, including intellectual intelligence (Daniel Goleman, 1996). Cognitive ability or intellectual intelligence (IQ) contributes only about $20 \%$ to the success of public life (academic, personal and occupational) while the remaining $80 \%$ is directly attributed to EI (Adrian Furnhan dalamAnnamaria Difabio, 2012). While Daniel Goleman says that intellectual intelligence (IQ) contributes about 20\% determines the success of life, $80 \%$ determined non-IQ factors, such as social class to luck. (Daniel Goleman, 1996).

There are many research facts that show that emotional intelligence (EQ) plays a role in one's life, be it in work, adjustment, and decision making. The emotional intelligence (EQ) of a person will increase his or her productivity in work and a better working environment (Chin S.T.S., et al., 2011). Emotional intelligence (EQ) affects adolescent self-adjustment, adolescents with high emotional intelligence (EQ), then their adjustment is stable (good) (Jose M. Salguero, et al., 2012). High emotional intelligence will have a positive effect on effective decision making (S.P. Chauhan, 2007). Social and emotional intelligence affects life and success and failure (Suzane, B, 2003). Emotional intelligence (EQ) and intellectual acumen (IQ) are positively correlated with performance (Sthephane Cote et al., 2006). Managers included in top management levels have a much higher level of emotional intelligence and therefore they excel in decision making, and their roles are higher than that of middle and lower level managers. High levels of emotional intelligence can contribute positively to effective decision-making and thereby play an effective role for managers, as there is a positive correlation between emotional intelligence and decision-making and role efficacy (S.P. Chauhan et al., 2007). There is a relationship between emotional intelligence and performance becoming more positive (Stephane Cote et al., 2006).

During this time the theory of psychology (including the theory of emotional intelligence) more widely known and taken from the modern psychology is already established and popular than the psychology of Islam is still new. Islamic psychology appears to build a formulation of psychological concepts with insightful Islam in an effort to realize the psychology that can seated human beings in accordance with the potential and role. The presence of Islamic psychology because Islam has the tools needed to build the psychology of Islam itself. Islam (through the Qur'an, hadith and the treasury of iskam thought) has spoken much about man and his approach to solving human problems. The concept of Islamic psychology comes from Alqur'an and Hadith, while the concept of western psychology is derived from western psychologists (Djamuluddin Ancok, et al., 1994). As a Muslim scientist, it is supposed to develop this Islamic psychology without having to deny the theories of western psychology. Therefore, dialogue both (western psychology and Islamic psychology) is a wise thing.

This paper tries to illustrate the theory of emotional intelligence from the perspective of western psychology and Islamic psychology in the framework of building a dialogue between the two concepts of science.

\section{Emotional Intelligence (EQ) In the Concept Of Psychology}

Emotion is literally every activity or pereminance of mind, feeling, lust, every great mental state or overwhelming (Yatim Riyanto, 2009). All the emotions, in effect, the impulse to action, the instant plan to live the life that evolution has infused within. The root of the word emotion is motere, the latin verb "moving," plus the prefix "e-" which connotes "away," indicates that the tendency to act is implicit in every emotion. Emotions are a stimulating impulse to act - apart from real reactions. (Daniel Goleman, 1996) 
Emotional intelligence is the ability to understand the environment (politics, social) and rearrange, understand what others want to be fun for other people (Hamdani Bakran, 2008). This definition by the author is less comprehensive because it only emphasizes the emotions of others only, while self-emotion is ignored. Another more comprehensive definition is that the emotional intelligence is able to regulate the emotional atmosphere in the form of receiving, understanding and managing it (Makmun Mubayidin, 2007). Patricia Patton (in Orphan Riyanto, 2009) says that emotional intelligence is a person's ability to use (manage) his emotions effectively to achieve goals, build productive relationships with others and achieve success in the workplace (Yatim Riyanto, 2009).

Aspects of emotional intelligence according Daniel Goleman in his book there are five that is to recognize the emotions (self awareness) which is the key word of emotional intelligence, managing emotions based on self awareness, self-motivation, recognize the emotions of others (empathy) able to establish relationships with others (social competence) (Daniel Goleman, 1996).

1. Self awareness is an awareness of the mood and views of the mood located in the brain neocortex, especially the area of the language that serves to identify and name emosions that arise.

2. Managing emotions is the ability to manage moods such as fear, anxiety, sadness, and others, experienced during the execution of activities so they feel better

3. Self-motivation (self-motivation) is the ability to motivate and master yourself. Emotional self-control (postpones distressing satisfaction and pressure) People with these skills tend to be more productive and effective in whatever they do

4. Recognizing the emotions of others (empathy) is able to understand the feelings of people by being able to read nonverbal signs of the feelings of others such as intonation of voice, gesture, facial expression, and others.

5. Relationship with others (social competence) is the ability of a person to confront, to mobilize and motivate others, to develop in intimate relationships, to persuade and influence, to make others feel comfortable.

\section{Emotional Intelligence In The Concept Of Islamic Psychology}

In Islam, the word emotions or feelings related to intelligence can be understood from the Word of Allah following (Hamdani Bakran, 2005) :

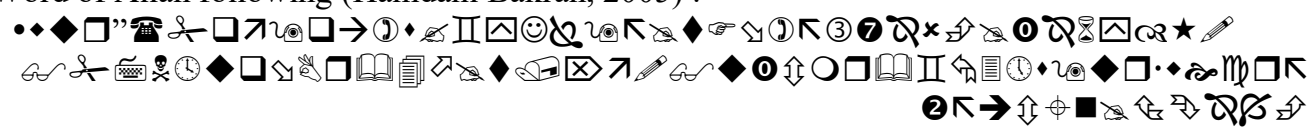

And do not say to those who are slain in the way of Allah, (that they are) dead; even they are alive, but you are not aware of it (Surah Al-Baqarah [2]: 154)

The verse explains how humans are able to maintain the feelings of others by keeping verbal. Although it is true that the martyrs are dead, the feelings of the abandoned must also be preserved by relaying the sad news to the situation, the right conditions and the right way. This is a picture of emotional intelligence (Hamdani Bakran, 2005).

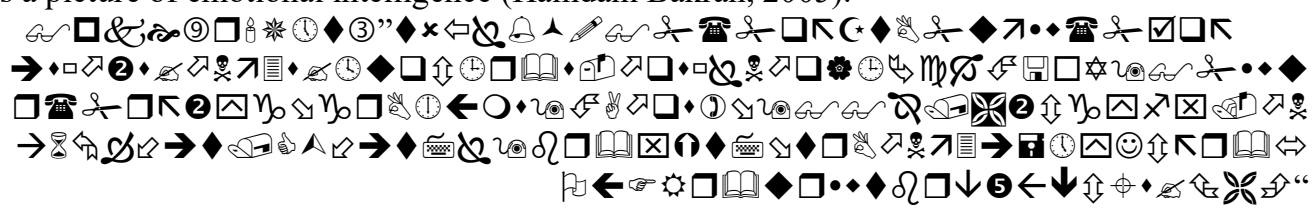


who believe, do not raise your voice above the voice of the Prophet, and do not speak to him in a loud voice, as the loud voice of some of you against others, so as not to remove (reward) your deeds while you are unaware (Surah Al -Hujarat [49]:2)

The verse describes the prohibition of speaking out loud including to the Prophet. It has the meaning that how to communicate to others will affect the feelings of others. people with emotional intelligence will understand this (Hamdani Bakran, 2005).

In Islamic perspective the traits of people who have emotional intelligence are described as follows:

1. Sowing affection on earth

People who have emotional intelligence then he will love all the creatures of God. Allah SWT. and the Messenger of Allah is clear in the word and hadith states how important each other loves this to others, do not hurt each other let alone kill each other (Hamdani Bakran, 2005). The Word of God which reads:

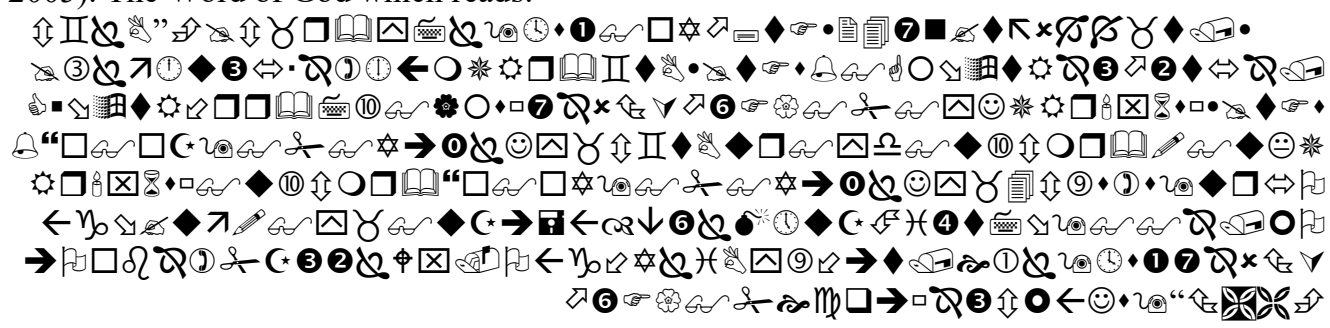

Therefore We decreed (a law) for the Children of Israel, that: who kills a man, not because of that person (kill) another person, or not for making mischief in the earth, So it is as if he has killed all humanity. and whoever preserves the life of a human being, So it is as if he has preserved all human life. and verily has come unto them Our Apostles with (bring) clear explanations, and many of them afterwards have indeed exceeded the limits of corruption in the earth (Surah Al-Maidah [2]: 32).

The word أجلجل means (meaning a crime that is feared to happen), because of or caused "to mean" either because of the crime or not ". In the above verse it means "caused by the crime of murder that is feared will happen. The use of the word على (above) means "obligation" ie the law's stipulation is addressed to the Children of Israel on the basis of an obligation for them to obey it. The Children of Israel are mentioned in this verse because the ugliness they have done is very much in the killing, because the one they killed was a prophet and an Apostle. The above verse implies that all human beings (regardless of tribe, race of religion and descendants) are equal in human terms therefore, when killing an innocent person is the same as killing all human beings (Quraisy Shihab, 2004).

The word ثمبإكثير امنهمبعدفالأرضلمسرفون denotes a distant level of extent beyond which, after there is concrete evidence, the Israelites are increasingly disobeying, then this is later (ن). This verse includes the four emphases of "the word then", the word "inna (the real)", the word "earnest" and the word "musrifuun" (Quraisy Shihab, 2004).

This is confirmed by the following hadith of Rasulullah SAW:

$$
\text { “وأمِؤمن لمؤمن كابنيان يشد بعضه بعضا وشبك بين أصابعه” }
$$

a believer to another believer is like a building that reinforces one part of it with another like his fingers. (H.R. Bukhari and Muslim and Abu Musa Ra)

2. Understand the feelings and circumstances of others

A person who emotionally intelligent will be able to understand the feelings and conditions of others, so that he or she guards the oral, attitudes and deeds that will hurt others. 
Allah SWT. not impose his will on his servant in performing his worship to Him. As His Word follows:

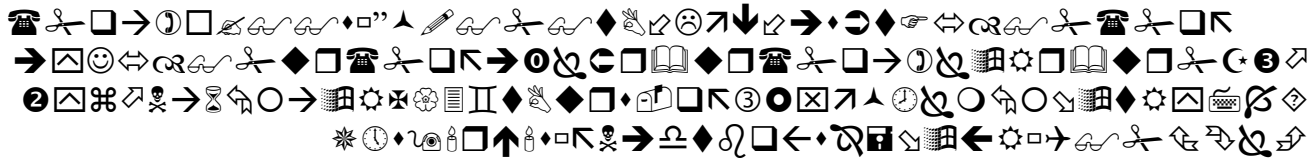

So fear Allah according to your abilities and listen and obey and spend a good living for you. and whoever is kept from his own mind, So they are the ones who are lucky.

Likewise with the Prophet very understand the state of his people so that every remark and his actions always consider the circumstances and feelings of his people. For example when he asked the prayer imam not to be long-winded in the prayer because the condition of the different (not all of them are healthy), such as the following hadith (Hamdani Bakran, 2005):

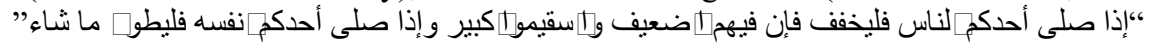

if one of you as a prayer priest for the people, he should lighten up because among the people there are weak people, who are sick and parents. And if prayer itself, then panjangkanlah as best (H.R. Bukhari and Muslim from Abu Hurairah Ra)

3. Respecting and appreciating oneself and others

Respecting and respecting yourself means taking care of physical and psychological cleanliness to avoid physical and psychological illness as well. While respecting and respecting others is not doing something that doubles the peace of mind, heart and personal rights of others. It is also commanded by God to curse those who hurt his brother (Hamdani Bkara, 2005), as Allah says:

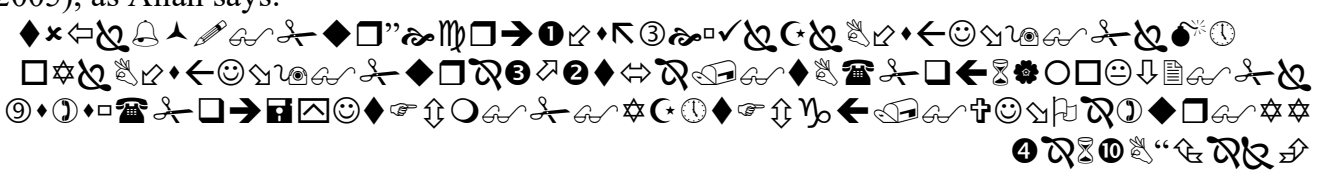

And those who hurt the believers and the cultivators without their mistakes, then surely they have borne the lies and the real sin.

\section{Muraqabah (alert and introspective)}

Muroqabah is self-consciousness that God always sees him(Hamdani Bakran, 2005). As the word of Allah swt. following:

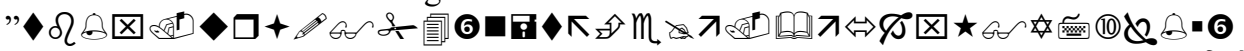

And Allah is all-watchful of all things (al-Ahzab [33]: 52)

The word رقيا means to appear perpendicular to keeping something. The God of raqiib means that He is always watching, watching, watching His creatures (Quraisy Shihab, 2005).

\section{Friendly to the environment}

The relationship of man to nature is the relationship of togetherness in obedience to Allah SWT, not the relationship between master and servant. Therefore, humans are obliged to maintain the environment that exists around it whether it is nature, plants, and so on (Hamdani Bakran, 2005). 


\section{Conclusion}

Based on the above explanation it can be concluded that the concept of emotional intelligence in the perspective of psychology and Islamic psychology has the side of similarities and differences. The similarities and differences between the two perspectives lies in the aspect of emotional intelligence. The similarity of both perspectives in explaining aspects of emotional intelligence is on the aspect of empathy, only in the concept of Islamic psychology using other terms.There are things that are not covered in the emotional intelligence aspect of the psychology of the psychology while in Islamic psychology explain it. Islamic psychology is broader in scope than in western psychology. In Islamic psychology, muraqabah (selfawareness that God always sees itself) and is friendly to the environment (such as plants, the universe, animals, etc.) are an aspect of emotional intelligence. This is what distinguishes the concept of emotional intelligence in the perspective of western psychology and Islamic psychology.

\section{References}

[1.] Amram Y., (2016)., What is Spiritual Intelligence? An Ecumenical, Grounded Theory. 18

[2.] Bakran H. Adz-Dzakiey, 2005., Prophetic Itelligence:Kecerdasan Kenabian, Menumbuhkan Potensi Hakiki Insani Melalui Pengembangan Kesehatan Ruhani, Yogyakarta: Islamika

[3.] Bakran H. Adz-Dzakiey., dkk., (2005). Prophetic Intelligence: Constract Development and Empirical Test for Its Role in the Perception of Unethical Conduct Among Indonesian Goverment Employess. Jurnal Psikologi Islam, 1 (1).

[4.] Chin, S. T. S., Anantharaman, R. N., \& Tong, D. Y. K. (2011), The Roles of Emotional Intelligence and Spiritual Intelligence At The Workplace. Journal of Human Resources Management Research, b1-9

[5.] Goleman D., (1996)., Emotional Intelligence: Why It Can Matter More Than IQ, London: Bloomsbury Publishing

[6.] Jose M. S., Raquel P., and Pablo F.B., (2012)., Perceived Emotional Intelligence As Predictor of Psychological Adjustment In Adolescents: a1-year Prospective Study, European Journal of Psychology of Education, Vol. 27, No. 1., pp. 21-34

[7.] Mubayidin M,(2007)., Kecerdasan dan kesehatan emosional anak: referensi penting bagi para pendidik dan orantua, Jakarta: Al-kautsar

[8.] Riyanto Y., (2009)., Paradima Baru Pembelajaran: Sebagai referensi bagi pendidik dalam implementasi pembelajaran yang efektif dan berkualitas, Jakarta: Kencana

[9.] S. P. Chauhan and Daisy Chauhan, 2007., Emotional Intelligence: Does It Influence Decision Making and Role Efficacy?, Indian Journal of Industrial Relations, Vol. 43, No. 2 (), pp. 217-238

[10.] Stéphane C. dan Christopher T. H. Miners, (2006)., Emotional Intelligence, Cognitive Intelligence, and Job Performance, Administrative Science Quarterly, Vol. 51, No. 1, pp. 1-28

[11.] Suzanne B., (2003)., Social and Emotional Intelligence: Applications for Developmental Education, Journal of Developmental Education, Vol. 26, No. 3.,Spring, pp. 28-30, 32, 34

[12.] Quraisy M. S., (2004).,Tafsir Al-Misbah: Pesan, Kesan dan Keserasian Al-Qur'an, Vol 9, Jakarta: Lentera Hati 